\title{
Politik Hukum Undang-Undang Pemilihan Presiden 2009
}

\author{
Mirza Satria Buana \\ FH Unlam Jl. Hj. Hasan Kasri Kayu Pange Banjarmasin \\ mirzabjn@yahoo.com
}

\begin{abstract}
Normatively, an act, in whatever form in may be, shall be based on the orientation for the the people benefit and to ascertainment of the justice for people. The politics of law of presidential election issued by the relevant body is considered to be conservative and tends to be elitical. On theother hand, the success of Indonesia to exit fron the transition of democracy is determined by the lagal policiy of the govenrment. Through the issuance of act on Presidential election which is responsive, a better and more democratic new president may be ekected.
\end{abstract}

Keywords : Democracy, Politics Of Law, Presidential Election

\section{Pendahuluan}

Selama ini Indonesia mengaku sebagai negara yang berorientasi kepada bentuk negara demokrasi (democratic state), namun dalam perkembangan sejarah dan aplikasi empiris, negeri ini belumlah menemukan sebuah format ideal negara demokrasi. Tercatat dalam sejarah ketatanegaraan Republik Indonesia, seringnya terjadi bongkar pasang sistem pemerintahan dan bentuk negara, seperti pergantian pada masa demokrasi liberal menjadi demokrasi terpimpin (1945-1959). Pada masa ini bentuk negara berubah dari negara kesatuan menjadi negara federasi lewat UUD RIS 1949 dan menjadi negara kesatuan lagi lewat UUDS 1950. Masa itu ditandai dengan corak pemerintahan yang liberal (demokrasi liberal) dan corak kepemimpinan Soekarno sangat otoriter (demokrasi terpimpin). ${ }^{1}$

Dalam konteks kekuasaan eksekutif, Indonesia memang sering terjebak dalam motif "balas dendam". Pada masa pemerintahan demokrasi liberal

${ }^{1}$ Moh.Mahfud MD, Politik Hukum di Indonesia, sLP3ES, Jakarta, 2006, hlm.129 
(1945-1959), Presiden Soekarno dibuat "geram" oleh tingkah polah partai politik yang pada masa itu saling baku hantam (free fight) di parlemen, yang mengakibatkan gagalnya penyusunan UUD oleh Konstituante dan instabilitas politik sangat sering terjadi dengan sering tumbangnya kabinat-kabinet pada masa itu. Reaksi dari liberalisme politik tersebut adalah dikeluarkannya Dekrit Presiden Soekarno yaitu Dekrit Presiden 5 Juli $1959^{3}$ yang menyatakan: Presiden Soekarno menjadi Presiden seumur hidup, membubarkan parlemen dan mengganti corak demokrasi liberal menjadi demokrasi terpimpin (otoritarian).

Demokrasi Terpimpin berangkat dari sebuah kerangka filosofis bahwa suatu negara haruslah memiliki sistem pemerintahan yang berdasar pada asas musyawarah dan mufakat, dengan dipimpin oleh kekuasaan sentral sebagai penyambung lidah rakyat. ${ }^{4}$ Kekuatan sentral tersebut tidak lain dan tidak bukan adalah Soekarno sendiri.

Dalam ranah aplikatifnya, demokrasi terpimpin tidak berjalan sebagaimana yang diharapkan dan dicita-citakan oleh Soekarno sendiri. Godaan otoriter dari sistem demokrasi terpimpin tidak bisa dihindari terjadi pada masa itu, garis politik Soekarno yang sangat represif terhadap kebebasan pers, dan anti pemilihan umum ditambah dengan "mesranya" Soekarno dengan Partai Komunis Indonesia(PKI), semakin memperparah rasa kepercayaan rakyat kepada dirinya.

Transisi kekuasaan terus terjadi ketika Soeharto melengserkan Presiden Soekarno dari singgasana kekuasaan pada tahun 1965, Soeharto memerintah dengan sebuah credo "menjalankan Pancasila dan UUD 1945 dengan murni dan konsisten", Sayangnya corak demokratis pemerintahan Soeharto hanya berjalan kurang lebih 3 tahun, sebelum Soeharto menentukan format kekuasaannya yang sebenarnya melalui rekayasa produk hukum yang sangat otoriter dan elitis (Undang-Undang Pemilu No.15 dan Undang-Undang Susduk MPR, DPR, dan DPRD No.16 Tahun 1969). ${ }^{5}$

Selama Orde Baru, HAMSipil dan politik banyak dilanggar dengan alasan untuk menjaga stabilitas politik demi kelancaran pembangunan ekonomi. Korupsi, Kolusi,dan Nepotisme (KKN) merajalela, penyalahgunaan

${ }^{3}$ Wirjono Prodjodikoro menyebut staatnoordrecht yang juga berdasarkan atas prinsip salus populi supreme lex (keselamatan rakyat adalah dasar hukum yang tertinggi) sebagai dasar hukum dekrit tersebut.

${ }^{4}$ A.Syafie Maarif, dalam Moh.Mahfud MD, Politik Hukum ...Op.Cit., hlm.140

${ }^{5}$ Moh.Mahfud MD, Ibid., hlm. 222 
kekuasaan meluas, dan hukum merupakan subordinasi dari kekuasaan politik. ${ }^{6}$ Hilangnya peran hukum dalam kehidupan sosial politik ternyata telah mengakibatkan perjalanan bangsa menjadi tidak terarah. Artinya proses evaluasi sosial politik tidak memiliki nilai positif, bahkan pada akhirnya menjadi destruktif. ${ }^{7}$ Lewat produk-produk hukum yang dikeluarkan oleh pemerintahan Orde Baru tersebut, kekuasaan rezim Soeharto menjadi lestari dengan cara yang kolusif lebih dari 32 tahun lamanya.

Setelah 32 tahun kekuasaan otoriter Soeharto, negara ini mendapatkan pelajaran berharga betapa pentingnya nilai-nilai dari negara hukum baik "rechsstaat" maupun "rule of law" (yang sesungguhnya), seperti: pengawasan terhadap pemerintah (controlling the executive), pemisahan kekuasaan (separating power), penghormatan kepada Hak Asasi Manusia (constitutions based of human right), independensi dan ketidakberpihakan institusi pengadilan (independent and impartial judicial system), dan pengawasan peradilan (court monitoring). ${ }^{8}$

Indonesia, sekarang berada dalam iklim reformasi yang merupakan sebuah jalan yang terjal menuju cita-cita negara demokrasi. Salah satu jalan terjal yang harus dihadapi adalah mekanisme pemilihan secara langsung oleh rakyat (direct election), pada medio tahun 2004, dimana pada saat itu terpilih untuk pertama kali Presiden dan Wakil Presiden yang dipilih langsung oleh rakyatnya. Tidak bisa dinafikan bahwa pemilihan umum tahun 2004 masih terdapat banyak kekurangan di sanasini, namun tidak bisa dinafikan juga, bahwa pemilihan umum tahun 2004 yang lampau merupakan milestone dari proses perjalanan demokrasi Indonesia.

Setelah lebih dari 10 tahun reformasi bergulir, bangsa Indonesia menjadi bangsa yang berdialektika, cerdas dan tanggap terhadap fenomena sosial di masyarakat maupun dalam scope negara. Banyak saran-saran dari para ilmuwan hukum dan politik negeri ini yang sangat berarti untuk tumbuh kembangnya negara hukum Indonesia. Salah satu wacana kontemporer yang menarik untuk dibahas adalah perihal pemilihan presiden untuk tahun 2009 mendatang. Pemilihan Presiden

${ }^{6}$ Ni'matul Huda, Negara Hukum, Demokrasi dan Judicial Review, FH UII Press, Yogyakarta, hlm. 24 hlm. 141

7 Artidjo Alkostar, Korupsi Politik di Negara Modern,FH UII Press, Yogyakarta,

${ }^{8}$ A.Mukthie Fadjar. Reformasi Konstitusi dalam Masa Transisi Paradigmatik, In-TRANS, Malang, 2003, hlm.9 
menjadi momentum yang sangat krusial bagi gerak maju demokratisasi dalam mencapai cita-cita negara hukum Indonesia.

Dalam rangka menyambut pemilihan umum tahun 2009, Dewan Perwakilan Rakyat (DPR), diberi wewenang berdasarkan UUD 1945 untuk merancang dan mengesahkan Undang-Undang Pemilihan Presiden, yang nantinya akan digunakan sebagai payung hukum pelaksanaan pemilu tersebut. Dalam hal pembuatan undang-undang, faktor pertimbangan politik sangatlah berperan, dan tidak jarang mengabaikan pertimbangan hukum. Hal ini terlihat jelas pada substansi UndangUndang Pemilihan Presiden yang disahkan pada tanggal 29 Oktober $2008 .{ }^{9}$ Dalam Undang-Undang Pemilihan Presiden tersebut disyaratkan dukungan 20 persen kursi legislatif dan 25 persen suara dari suara sah pemilu sebagai syarat pencalonan Presiden. Hal tersebut menimbulkan pro dan kontra di masyarakat pada umumnya, dan para praktisi hukum dan politik pada khususnya. Pertanyaan yang mendasar dari disahkannya UU Pemilihan Presiden tersebut, adalah: Politik hukum apa yang mendasari dikeluarnya Undang-Undang tersebut? Bagaimana seharusnya politik hukum (ius contitundum) untuk masa depan hukum Indonesia yang lebih baik?

\section{Undang-Undang Pemilihan Presiden No. 42 Tahun 2009 Elitis}

Undang-Undang secara normatif, apapun bentuknya pasti berorientasi kepada kemaslahatan masyarakat luas, dan mengayomi nilainilai keadilan dalam masyarakat. Karena itulah apabila suatu produk hukum/undang-undang tertentu terbukti hanya akan menguntungkan segelintir oknum (elitis) tertentu maka undang-undang tersebut "batal demi hukum" sebagai produk hukum yang responsif dan demokratis.

Namun apabila dipandang dari realitas sosial-politik kontemporer, sungguh tidak dapat dinafikan bahwa hukum yang kemudian dikonkritkan dalam suatu bentuk produk hukum (undang-undang) tidaklah berada dalam keadaan yang netral, tetapi merupakan entitas yang berada pada suatu environment yang saling kait-mengait dan mempengaruhi satu sama lain. ${ }^{10}$ Kesimpulannya, undang-undang

\footnotetext{
${ }_{9}^{9}$ Koran Tempo, "Syarat Calon Presiden Dinilai Hambat Partai Baru", Kamis,30 Oktober 2008, Hlm.A5

${ }^{10}$ Afan Gaffar, "Pembangunan Hukum dan Demokrasi", dalam Moh.Busro Muqaddas dkk (Penyunting), Politik Pembangunan Hukum Nasional, UII Press,1992, hlm.104
} 
merupakan produk dari berbagai elemen-elemen, seperti elemen politik, ekonomi, sosial, dan budaya. Hal ini yang mengakibatkan pembuatan dan eksistensi suatu perundang-undangan sangatlah tergantung kepada elemen-elemen yang berada di luar hukum.

Kesimpulan di atas dipertajam kembali oleh Moh.Mahfud MD, yang mengatakan bahwa hukum (undang-undang) merupakan produk politik semata, sehingga responsif atau tidaknya suatu produk hukum mutlak ditentukan oleh konfigurasi politik itu sendiri. Melalui studi yang mendalam Moh.Mahfud MD memberikan penjelasan sebagai berikut : "konfigurasi politik yang demokratis akan melahirkan produk hukum yang responsif, sedangkan konfigurasi politik yang otoriter akan melahirkan produk hukum yang konservatif/ortodok". ${ }^{11}$ Hipotesa tersebut berangkat dari jenis hukum tertentu yaitu untuk hukum-hukum publik yang sangat dekat dengan kekuasaan politik (gezagverhoulding), sehingga semakin sarat isi hukum yang terkait dengan politik, maka semakin signifikan peranan politik dalam pembuatan hukum (undangundang) tersebut.

Namun sebuah pertanyaan kritis yang patut dipertanyakan sekarang adalah : setelah lepas masa otoriter Orde Baru, mengapa produk-produk hukum masih saja bersifat konservatif dan cenderung elitis? Walaupun kita sudah menjalani lebih dari 10 tahun masa reformasi, kapan hukum akan tegak dan dihormati? Setelah lepas lima tahun berjalan, pemerintah dan lembaga perwakilan rakyat (DPR) hasil Pemilu 2004 kini menuai kritik dan cercaan. Mantan Ketua MPR Amien Rais menilai bahwa DPR periode 2004-2009 sebagai tukang stempel kebijakan pemerintah semata. Hal ini dapat dilihat dari undang-undang yang dihasilkan pada tahun pertama, DPR hanya menghasilkan 14 undang-undang dari 55 rancangan undangundang yang ditargetkan. Undang-undang tersebut secara substansial bukanlah kebutuhan mendesak rakyat, misalnya UU Olahraga, UU Pengadilan Tinggi Agama, dan beberapa ratifikasi konvensi internasional. ${ }^{12} \mathrm{Hal}$ di atas diperparah oleh orientasi para legislator ditubuh DPR yang lebih mementingkan kepentingan politik/elitis ketimbang menegakkan kedaulatan rakyat (people supremacy).

\footnotetext{
${ }^{11}$ Moh.Mahfud MD, Op. cit., hlm.5

${ }^{12}$ FORMAPPI, "Evaluasi Satu Tahun DPR Hasil Pemilu 2004", dalam Sebastian Salang, Jurnal Konstitusi, Volume 3 Nomor 4, Desember 2006
} 
Sebuah asumsi dasar mengemuka dalam sub judul ini, para legislator di DPR, yang merumuskan dan menggodok Undang-Undang Pemilihan Presiden, diindikasikan terjebak dalam political dillema, di satu pihak mereka masih tersandera oleh kepentingan-kepentingan partai politik pengusung mereka (political hijacking in law process), di pihak lain kedudukan mereka sebagai wakil rakyat yang terhormat, (yang seharusnya) hanya berorientasi kepada kepentingan masyarakat luas dengan tetap berkaca pada "cermin yuridis". Hal tersebut sesuai dengan definisi yang diberikan oleh Bryan A. Garner, yang menyatakan:"Legislator is making or giving laws; pertaining to the function of law making or to the process of enactment of law with independent and neutral from any other influences". ${ }^{13}$

Tetapi sayangnya, faktor tersandera oleh kepentingan partai politiklah yang mereka pilih, sehingga kebijakan-kebijakan pro kepentingan partai masih sangat vulgar diperlihatkan oleh para wakil-wakil rakyat tersebut. Idealnya kesetiaan legislator pada partai politik akan berakhir ketika para legislator tersebut duduk di kursi parlemen, karena yang mereka wakili bukanlah partai politik semata namun rakyat Indonesia. Itulah esensi utama dari kedaulatan rakyat yang terjewantahkan dalam prinsip kemerdekaan legislatif (Independence of legislative). "The independence of legislative is not limited only to the executive pressure or influence, it is a wider concept which takes within it is sweep independence from any other pressure and prejudices, it include parties influences". ${ }^{14}$

Dalam konstitusi (Undang-Undang Dasar 1945) juga dinyatakan bahwa, kedaulatan berada di tangan rakyat dan dilaksanakan menurut Undang-Undang Dasar. Hal ini dituangkan dalam Alinea IV Pembukaan Undang-Undang Dasar 1945 yang menegaskan bahwa :"...maka disusunlah kemerdekaan kebangsaan Indonesia itu dalam suatu UndangUndang Dasar Negara Republik Indonesia, yang terbentuk dalam suatu susunan Negara Indonesia yang berkedaulatan rakyat". Pasca amandemen, konsep kedaulatan rakyat kembali dipertegas dalam Pasal 1 Ayat 2 UndangUndang Dasar 1945, bahwa "Kedaulatan berada di tangan rakyat dan dilaksanakan menurut Undang-Undang Dasar”. Salah satu wujud konkrit

${ }^{13}$ Bryan A. Garner, Black Law Dictionary, $8^{\text {th }}$ Edition, West Group,1999,United State of America,hlm.864

${ }^{14}$ Justice L.P. Singh, Judicial Dictionary, $2^{\text {nd }}$ edition, Orient Publishing Company, 2001, New Delhi, hlm. 569 
dari kedaulatan rakyat adalah penyelenggaraan pemilu untuk memilih Presiden dan Wakil Presiden yang dilaksanakan secara demokratis dengan melibatkan partisipasi rakyat seluas-luasnya. ${ }^{15}$ Konstitusi secara jelas dan tegas menunjukkan bahwa kedaulatan ada di tangan rakyat. Rakyat adalah pemegang atau pemilik kedaulatan dalam negara.

Selanjutnya, kembali dipertegas dalam konsideran menimbang huruf (a) UU No.22 Tahun 2003 Tentang Susduk MPR, DPR, DPD dan DPRD, yang menyatakan : " bahwa untuk melaksanakan kedaulatan rakyat atas dasar kedaulatan yang dipimpin oleh hikmat kebijaksanaan dan permusyawaratan/perwakilan perlu diwujudkan lembaga permusyawaratan, lembaga perwakilan rakyat dan lembaga perwakilan daerah yang mampu mencerminkan nilai-nilai demokrasi serta dapat menyerap dan memperjuangkan aspirasi rakyat dengan tuntutan perkembangan kehidupan berbangsa dan bernegara. ${ }^{16}$

Melalui amanah UUD 1945 dan UU No.22 Tahun 2003 di atas, tidak bisa dipungkiri bahwa secara substansial, Undang-Undang Pemilihan Presiden yang memberikan batasan 20 persen kursi legislatif dan 25 persen suara dari suara sah pemilu untuk menjadi syarat pencalonan calon presiden, jelas sangat menguntungkan partai-partai lama yang sudah wellestablish di DPR (seperti Golkar dan PDI-Perjuangan), yang secara langsung telah mencederai amanah konstitusi dan nilai-nilai demokrasi dalam bernegara, karena dalam sistem ketatanegaraan yang demokratis, pemilu dipandang sebagai instrumen pokok demokrasi (crucial democracy instrument) yang bertujuan untuk mewujudkan cita-cita demokrasi. Demokrasi menolak monopoli dalam proses pemilu, yang akan berefek buruk kepada hak-hak politik dari kalangan minoritas.

Logikanya, dengan jumlah partai politik yang membengkak menjadi 44 buah partai politik pada pemilu 2009, akan sangat sulit bagi partaipartai baru (yang mengusung calon-calon presiden alternatif) untuk mendapatkan 20 persen kursi legislatif dan 25 persen suara dari suara sah. Bad ending-nya bisa ditebak hanya partai-partai yang besar dan wellestablish di DPR yang dapat mencalonkan calon presidennya, sedangkan

${ }^{15}$ Dahlan Thaib, Makalah: "Prospek Pemilihan Calon Presiden Independen, disampaikan dalam seminar nasional "Prospek Pemilihan Calon Presiden Independen" yang diselenggarakan oleh Pusat Studi Pembangunan Hukum Lokal FH UII bekerjasama dengan Merti Nusantara Yogyakarta, Auditorium UII Yogyakarta, 20 Desember 2008

${ }^{16}$ UU No.22 Tahun 2003 tentang Susduk MPR, DPR, DPD dan DPRD 
partai-partai kecil harus rela berkoalisi dengan mengorbankan ideologi mereka untuk dapat mencalonkan calon presiden alternatifnya.

Nantinya akan menjadi sebuah ironi, ketika rakyat sebagai penentu proses demokrasi harus tersenyum masam ketika disodori kartu pemilih yang mencantumkan 2 (dua) atau 3 (tiga) foto calon pasangan presiden dan wakil presiden (incumbent) yang sudah cukup familiar dimata masyarakat dikarenakan kinerja yang tidak memuaskan.

Berangkat dari sebuah adagium, yang menyatakan hukum yang adil menumbuhkembangkan demokrasi. Sebaliknya, hukum yang korup menikam mati demokrasi. Itu sebabnya mengapa Undang-Undang Pemilihan Presiden yang baru disahkan oleh DPR ini harus ditolak, karena sangat kental dengan 'aroma busuk' politisi dan terkesan elitis. Harus ada keberanian untuk mengajukan uji materiil (judicial review) terhadap UndangUndang Pemilihan Presiden ini ke meja merah Mahkamah Konstitusi, karena undang-undang tersebut terbukti telah melanggar prinsip-prinsip kebebasan dalam berpolitik (Pasal 28E tentang Hak Asasi Manusia) yang secara tegas tercantum dalam Undang-Undang Dasar 1945 dan Konvensi Internasional tentang Hak Asasi Manusia yang telah diratifikasi Indonesia menjadi UU No. 39 Tahun 1999 Pasal 43, yang menyatakan:

(1) Setiap warga negara berhak untuk dipilih dan memilih dalam pemilihan umum berdasarkan persamaan hak melalui pemungutan suara yang langsung, umum, bebas, rahasia, jujur dan adil sesuai dengan peraturan perundang-undangan.

(2) Setiap warga negara berhak turut serta dalam pemerintahan dengan langsung atau dengan perantara wakil yang dipilihnya dengan bebas, menurut cara yang ditentukan oleh perundang-undangan. ${ }^{17}$

Pengekangan terhadap hak politik seorang warga negara dan penzholiman terhadap kaum minoritas merupakan bentuk abuse of the legislative process yang dilakukan oleh para legislators. Hal yang sama disebutkan oleh Karl Kurtz: Abuse of the process in order to prevent minority party members from accomplishing anything that reflect the values of their constituent, then you create a deep and bitter resentment. This resentment will come back to haunt you in myriad way. Abuse of the legislative process does not show strength but it shows weakness. ${ }^{18}$

${ }^{17}$ UU No. 39 Tahun 1999 tentang Hak Asasi Manusia, Pasal 43.

${ }^{18}$ www.ncsl.magazine.us. Karl Kurtz. Rules of legislative conduct, The Thicker at State Legislatures, NCSL website, di akses tanggal 7 Nopember 2008 
Selain alasan di atas, undang-undang tersebut juga tidak memenuhi asas kemanfaatan hukum (beneficial of law) dan keadilan dalam masyarakat ${ }^{19}$, yang seharusnya menjadi "roh" di dalam setiap produkproduk hukum yang dibuat oleh pemerintah.

Selain bertentangan dengan aturan hukum normatif, UU tersebut juga telah mencederai semangat filosofis dari gerakan reformasi dan demokratisasi di Indonesia, yang mana semangat reformasi dimaknai sebagai sebuah proses mencari format ideal demokrasi di Indonesia, dengan cara yang progresif, revolusioner, dinamis, dan berkesinambungan.

Bagaimana mungkin proses demokrasi akan berjalan cepat bila panggung politik Indonesia terus dihiasi oleh wajah-wajah lama yang malas pensiun dari panggung politik, implikasi dari itu semua adalah semakin berkuasanya para politisi-politisi busuk (rotten political) akan mempercepat pembusukan politik (political decay) di Indonesia. Rumusnya sederhana; pembusukan politik (political decay) terjadi karena hancurnya sistem politik oleh korupsi politik (political corruption), yang berasal dari kekuasaan monopolistik ( autonomy + monopoly), tanpa ada transparansi publik (- transparency). ${ }^{20}$ Lewat penjelasan di atas, tidak dapat dipungkiri kalau proses reformasi memerlukan re-generasi, pembaharuan dan peremajaan (re-new and re-fresh) sehingga perjalanan reformasi di Indonesia menjadi agenda yang tanpa henti dan berkelanjutan.

Menurut Ahmad Muzani, "seharusnya semua partai politik bisa mencalonkan, dan masyarakat yang akan menyaringnya", ${ }^{21}$ statement tersebut bisa menjadi pernyataan yang logis dari konsekuensi menerapkan sistem multi partai oleh Indonesia sekarang ini. Dengan dianutnya sistem multi partai, maka semakin rumit dan banyaknya partai politik, yang membuat semakin terpolarisasi dukungan kepada pemerintah, dan semakin besar potensi hadirnya pemerintahan yang terbelah (split government) sehingga melahirkan presiden minoritas (minority president). ${ }^{22} \mathrm{Hal}$ inilah yang membuat sistem multi partai sampai sekarang masih debatable, apakah bisa diaplikasikan dengan baik atau bahkan menjadi pemicu chaos dalam

${ }^{19}$ Tujuan utama dari hukum adalah: (1) kepastian hukum (legal certainly), (2) keadilan substansial (justice), dan (3) kemanfaatan (beneficial of law), ketiga elemen tersebut idealnya harus ada dalam setiap produk hukum negara.

${ }^{20}$ Denny Indrayana, "Negara antara ada dan tiada", Kompas, 2008, hlm.45

${ }^{21}$ Komentar Ahmad Muzani dalam Koran Tempo, Syarat Calon Presiden Dinilai Hambat Partai Baru, Kamis,30 Oktober 2008, hlm.A5

${ }^{22}$ Denny Indrayana, Op.Cit., hlm.180 
masyarakat.

\section{Politik Hukum Undang-Undang Pemilihan Presiden}

Sebuah pertanyaan kritis dilontarkan dalam sub judul ini, bagaimana seharusnya politik hukum (ius contituandum) untuk masa depan hukum Indonesia yang lebih baik? Terutama terkait konteks pengesahan UndangUndang Pemilihan Presiden di atas. Penulis akan mencoba memberikan rekomendasi sebagai berikut:

Pertama, Indonesia sampai saat ini belum dapat dikatakan sebagai negara demokratis, karena terbukti dalam proses pembuatan hukum (undangundang), para wakil rakyat (legislators) belum dapat memaknai semangat kedaulatan rakyat dengan benar, sehingga bukan rakyat yang berdaulat (demokrasi) tetapi para elit politik yang berkuasa. Inilah potret buram praktik oligarkhi yang ditunjukkan oleh para legislator. Ini merupakan lonceng peringatan pertama akan matinya demokrasi di Indonesia.

Kedua, Dewan Perwakilan Rakyat (DPR) sebagai lembaga yang diberikan wewenang oleh konstitusi (UUD 1945) untuk merumuskan undang-undang, harus lebih responsif dalam hal menyerap aspirasi rakyat dengan mencari nilai-nilai hukum di masyarakat (living law), sehingga undang-undang yang dibuat dapat lebih "membumi", "merakyat" dan jauh dari sifat elitis semata. Seperti yang dikatakan oleh Austin bahwa: "hukum yang terbaik adalah hukum yang ditransformasikan dari nilainilai di masyarakat".

Ketiga, konsep independensi haruslah dimaknai secara universal, bukan hanya ditujukan kepada calon presiden independen (yang memang lepas dari intervensi partai politik), tetapi juga harus menjadi nilai positif yang melekat pada diri para legislator-legislator di parlemen (inherent positive values of legislator). ${ }^{23}$ Legislator dalam hal pembuatan undang-undang, jangan lagi menjadi "kepanjangan tangan" partai politik, tetapi harus berorientasi kepada kepentingan rakyat yang mereka wakili. Kesetiaan kepada partai politik seharusnya sudah dienyahkan, ketika politisi tersebut sudah masuk dalam parlemen. Legislator harus bisa bekerja secara independen (bebas dari intervensi partai) dan professional, sehingga hasil kerjanya dapat memberikan manfaat bagi rakyat banyak. Dalam tulisan

${ }^{23}$ www.ncsl.magazine.us. Karl Kurtz. Rules of legislative conduct, The Thicker at State Legislatures, NCSL website, di akses tanggal 7 Nopember 2008 
ini, penulis mengkritisi mekanisme recall yang dimiliki oleh partai politik sebagai alat kontrol partai terhadap kadernya di parlemen. Hal ini dapat menjadi sebab ketakutan legislator kepada partai politik yang dulu mengusungnya, sehingga legislator terus "tersandera" oleh partai politik pengusungnya. ${ }^{24}$

Keempat, Salah satu ujung tombak reformasi hukum dan politik yang bertujuan untuk menumbuhsuburkan demokrasi, terletak pada tubuh partai politik. Itu sebabnya reformasi partai politik menjadi keharusan (urgently needed) dalam agenda reformasi. Partai politik, secara alamiah merupakan suatu institusi yang memberikan diferensiasi antara satu kelompok dengan kelompok lain. Dalam wilayah modernisasi politik, tidak ada peran tunggal yang maknanya lebih penting daripada politisi partai. ${ }^{25} \mathrm{Hal}$ ini dikarenakan partai-partai politik itu sendiri secara historis begitu erat kaitannya dengan proses modernisasi masyarakat di wilayah-wilayah yang berkembang. Peran partai sering berubah kalau kondisi politik disuatu negara berubah (terutama di masyarakat yang menjadi modern, dimana berbagai perkembangan politik bisa menyebabkan kepolitikan yang luas dan kompleks dari bentuk semula yang sederhana); dan di negara yang sedang berkembang terdapat hubungan yang khas antara negara dan masyarakat keduanya terkait bersama oleh solidaritas partai. Dalam konteks Indonesia, partai politik belumlah memenuhi kriteria sebagai partai modern, karena partai yang modern adalah partai yang mampu mengembangkan kemampuannya sesuai dengan tuntutan demokrasi, artinya partai politik harus dapat menjalankan peran perantara dalam hubungan negara dan rakyat. Kegagalan partai politik pasca reformasi dapat dilihat dengan semakin tingginya rasa ketidakpercayaan rakyat (distrust) terhadap partai politik, maupun terhadap calon presiden yang diusung partai politik. Dalam hal ini kita tidak perlu malu untuk menilai bahwa keputusan untuk menggunakan sistem multi partai terbukti kurang efektif untuk menumbuhkembangkan demokrasi di Indonesia. Karena itu penulis sepakat untuk mendorong proses reformasi partai, dengan cara (1) merekonstruksi sistem rekruitmen calon anggota partai politik, (2) Merekonstruksi pola komunikasi politik yang efektif dalam melakukan penyerapan aspirasi rakyat, dan (3) Memberangus budaya Korupsi, Kolusi dan Nepotisme (KKN) dalam tubuh partai itu sendiri.

${ }^{24}$ laporan International Transparancy, partai politik merupakan institusi terkorup di Indonesia.

${ }^{25}$ David E.Apter, Politik Modernitas, PT. Gramedia, Jakarta,1987, hlm.191 
Kelima, perlu dikaji ulang sistem multi partai yang diterapkan di Indonesia sekarang, karena terasa janggal bila sistem pemerintahan Indonesia presidensial tetapi terlihat sangat takut dan tanpa wibawa ketika berhadapan dengan parlemen, hal ini disebabkan oleh minimnya dukungan partai pengusung presiden di parlemen (minority president). ${ }^{26}$ Apabila Indonesia tetap benar-benar konsisten dengan sistem pemerintahan presidensial seperti sekarang ini dengan menetapkan batasan 20 persen kursi legislatif dan 25 persen suara dari suara sah untuk mencalonkan calon presiden, maka sebaiknya sistem kepartaiannya adalah dwi-tri partai saja, sehingga akan tercipta single majority dalam pemerintahan. Tetapi bila masih ingin menggunakan sistem multi-partai maka Undang-Undang Pemilihan Presiden pun harus lebih responsif dan realistis bagi partai-partai kecil, sehingga hak mereka untuk dapat mencalonkan calon presiden alternatif tidak terabaikan.

Keenam, pemerintah harus membuka kesempatan yang lebih luas dan jelas (dengan mengamandemen konstitusi/ UUD 1945) tentang calon presiden independen (non-partai), karena sebenarnya banyak sekali orangorang yang mapan secara intelektual, memiliki pengalaman dan memiliki integritas moral yang baik, teruji, dan bebas dari intervensi (penyanderaan) partai politik. Hal ini sejalan dengan adagium politik yang menyatakan : "Those to be reformed can not reform themselves, the reformers should come from the outsiders". Dengan majunya calon presiden independen, selain calon dari partai politik, akan meningkatkan kompetisi pemilihan presiden. Kompetisi yang fair akan mendorong demokratisasi, termasuk dalam tubuh partai politik sendiri.

Ketujuh, setelah pemilu tahun 2009 ada baiknya pemerintah mulai mempertegas aturan electoral threshold bagi partai-partai politik yang perolehan suaranya tidak mumpuni. Partai politik yang tersingkir secara alamiah tersebut diberikan kesempatan untuk memperbaiki diri dan organisasi kepartaian mereka untuk 2 periode pemilu ke depan, sehingga tercipta sistem kepartaian yang lebih sederhana, efisien dan demokratis. Dengan relasi sistem kepartaian yang lebih sederhana, akan tercipta hubungan ideal dalam sistem presidensial di Indonesia.

${ }^{26}$ Presiden Susilo Bambang Yodhoyono dengan Partai Demokrat sebagai mesin politik, pada Pemilu 2004 hanya mendapat kursi legislatif sebanyak 57 buah, dengan perolehan suara pemilu 2004,sebesar:8.455.225 atau sekitar 7,45\%). Sumber dari Koran Tempo, "Syarat Calon Presiden Dinilai Hambat Partai Baru", Op. Cit 


\section{Penutup}

Indonesia, memaknai proses demokrasi sebagai bagian dari urat nadi kehidupan berbangsa dan bernegara (inherently), dalam artian proses demokratisasi merupakan never ending process dalam lingkup negara demokrasi. Berhasil tidaknya Indonesia lepas dari masa tirani transisi demokrasi, ditentukan oleh legal policy dari pemerintah itu sendiri. Kedepannya pemerintah (eksekutif, legislatif dan yudikatif) perlu untuk membuat master plan yang disepakati bersama, sehingga kebijakan yang diambil dan dijalankan oleh masing-masing institusi tidak bersifat parsial dan kontradiktif melainkan saling tunjang dan sokong (check and balance) dalam hal penegakan kebijakan tersebut.

Pemilu 2009, diharapkan dapat menjadi titik tolak keberhasilan proses demokrasi di Indonesia. Diharapkan dengan didukung oleh produk hukum yang responsif, maka akan terpilih pemimpin baru Indonesia yang lebih baik dan demokratis.

\section{Daftar Pustaka}

Artidjo Alkostar, Korupsi Politik di Negara Modern,FH UII Press, Yogyakarta,2006.

Apter, David E. Politik Modernitas, PT. Gramedia, Jakarta, 1987.

A.Mukthie Fadjar, Reformasi Konstitusi dalam Masa Transisi Paradigmatik, In-TRANS, Malang, 2003.

Denny Indrayana, "Negara antara ada dan tiada", Kompas

Garner, Bryan A. Black Law Dictionary, $8^{\text {th }}$ Edition, West Group,1999,United State of America.

Ni'matul Huda, Negara Hukum, Demokrasi dan Judicial Review, FH UII Press, Yogyakarta, 2005

Moh. Mahfud MD, Politik Hukum di Indonesia,LP3ES, 2006.

Moh.Busro Muqaddas, dkk (Penyunting), Politik Pembangunan Hukum Nasional, UII Press, 1992

Singh, Justice L.P. Judicial Dictionary, ${ }^{\text {nd }}$ edition, Orient Publishing Company, 2001, New Delhi.

UU No.22 Tahun 2003 tentang Susduk MPR, DPR, DPD dan DPRD.

UU No.39 Tahun 1999 tentang Hak Asasi Manusia.

Jurnal Konstitusi, Volume 3 Nomor 4, Desember 2006

Dahlan Thaib, Makalah : "Prospek Pemilihan Calon Presiden Independen", disampaikan dalam seminar nasional "Prospek Pemilihan Calon 
Presiden Independen" yang diselenggarakan oleh Pusat Studi Pembangunan Hukum Lokal FH UII bekerjasama dengan Merti Nusantara Yogyakarta, Auditorium UII Yogyakarta, 20 Desember 2008

Koran Tempo, Syarat Calon Presiden Dinilai Hambat Partai Baru, Kamis, 30 Oktober 2008

www.ncsl.magazine.us. Karl Kurtz. Rules of legislative conduct, The Thicker at State Legislatures, NCSL website 